\title{
Research on the Status Quo of Waterfront Space Construction on the Macao Peninsula
}

\author{
Yiyang Li ${ }^{\circ}$, Luyang Tao, Yichen Feng \\ Faculty of Innovation and Design, City University of Macao, Macao, China \\ Email: yiyangli327@gmail.com
}

How to cite this paper: Li, Y.Y., Tao, L.Y. and Feng, Y.C. (2021) Research on the Status Quo of Waterfront Space Construction on the Macao Peninsula. Journal of Building Construction and Planning Research, 9, 292-312.

https://doi.org/10.4236/jbcpr.2021.94018

Received: October 10, 2021

Accepted: December 17, 2021

Published: December 20, 2021

Copyright $\odot 2021$ by author(s) and Scientific Research Publishing Inc. This work is licensed under the Creative Commons Attribution International License (CC BY 4.0).

http://creativecommons.org/licenses/by/4.0/

\begin{abstract}
Waterfront space is an important part of waterfront cities, and it carries the functions of ecological protection, tourism and urban landscape. As a city built on an island, Macao has abundant waterfront space. However, due to the geographical location, cultural and historical reasons, the waterfront space of Macao has a development gap in the use of urban waterfront space. The internal reasons for the differences in the waterfront space construction in which regions of the island are more perfect are the issues to be studied in this article. It is hoped that through the study of the current situation of Macao's local waterfront space infrastructure construction, the main points that affect advanced cases will be sorted out. From the location, industry, and infrastructure, find out its enlightenment to other waterfront spaces in Macao that are relatively backward in construction.
\end{abstract}

\section{Keywords}

Macao, Waterfront Space, Infrastructure

\section{Introduction}

The first attempts of redeveloping waterfronts began in North America during the 1960s in Baltimore and Boston, then in San Francisco [1], where, these projects became later models for the following revitalization projects developed in Europe and North America [2]. In the 1970s this kind of development gradually spread to the other parts of the world [3]. With the accelerating process of globalization and cities increasing their economic strength through the introduction of foreign capital, capital is also looking for suitable cities as a foothold. Many international cities have developed waterfront spaces as attractive economic centers. The appreciation of waterfront land has triggered an increase in traffic demand, and a more complete road system has been built, which has since 
led to a new round of land value enhancement. The renewal of urban waterfront space can often lead to the development of local commerce and tourism, as well as the revival of local history and culture [4]. Urban waterfront space attracts more investment, provides more jobs, and also brings more fiscal revenue to the city. The city's waterfront is a unique resource of the city. Under certain conditions and periods, it is often the core of the city's activity space and an important part of the city's spatial structure. In recent decades, the reconstruction and redevelopment of the waterfront area has become an important means for many cities to cope with the transformation of the urban socio-economic structure and global competition. The use of this method is closely related to the social and economic conditions of each city, and is formed and developed under the influence of certain social thoughts. The purpose of these transformations is to enhance the competitiveness of the city [5].

Judging from the requirements of the new round of China's territorial and spatial planning, waterfront space is an important part of building an ecologically civilized city. It is not only a very valuable production space with future potential, but also an ideal place for citizens to live and relax. It is the base of the ecological space with beautiful mountains and rivers, and it is also an important land space resource for sustainable development. On the other hand, the waterfront space of a city with a certain history is an important carrier of urban memory and a witness and bearer of urban history. The current construction and vitality of urban waterfront space is also a requirement for the protective development of urban space.

However, in actual observations, it is found that there is a gap in development in the use of urban waterfront space in Macao, and the waterfront space construction in some areas is more complete, which is favored by the public. In response to this question, which areas of the Macao Special Administrative Region's main island have more perfect waterfront space construction is the question to be studied in this article. The aim of the research is through the study of advanced local cases in Macao, we can find out its enlightenment to other waterfront spaces in Macao that are relatively backward in construction.

\section{Methods}

A field survey was carried out in the waterfront space of the Macao Special Administrative Region to record the construction of the waterfront space in Macao from three objective indicators of visibility, availability and openness of the infrastructure. The construction of service facilities is divided into six aspects: road connection, activity venues, greening, shading, seats, and equipment. Objectively record whether they are set up or not, and summarize the completeness of their services to the infrastructure construction in the table, and put it on the map. It is marked to make a summary of the construction status of the waterfront space in Macao.

\section{The Effect of Waterfront Space on Macao}

Many places and buildings in Macao have water in their names. Because Macao 
is an island city. Macao people have a deep feeling for water. At first, the fishery and shipbuilding industries in Macao were developed prosperous, and the waterfront space of Macao became a place for material production and external transportation. Nowadays, advanced production methods have changed the way of life of Macao people, and the space of the waterfront space has also undergone tremendous changes. In addition to transportation facilities such as wharves, the current waterfront space of the Macao Peninsula has become a collection of tourism, leisure, landscape, ecology conservation and other multi-faceted comprehensive space, but Macao people's memory of the history of waterfront space has never changed.

After the 1970s and 1980s, Macao's economy took off, and the city's social economy has made great achievements. Macao has transformed from an international trading port in history to a world-renowned casino and a world-class tourist city [6]. As an island city, Macao has a large number of waterfronts. However, due to the tense human-land relationship and the lack of space for urban development, the increasingly prominent issues have forced Macao to rush to expand by reclamation [7]. In 1991, the Macao government initiated the plan of reclaiming the Praia Grande. The reclamation work started in 1995 and was completed with two hemispheric basins-Nanwan Lake and West Bay Lake. lakes were divided into five parcels for mixed-use developments [8].

In 2016, China clearly stated in the "13th Five-Year Plan" that "support Hong Kong and Macao to play an important role in Pan-Pearl River Delta cooperation, and promote the construction of major cooperation platforms in the Guangdong-Hong Kong-Macao Greater Bay Area and across provinces and regions". Hong Kong and Macao should work with Guangzhou and Shenzhen to promote regional development and build a world-class urban agglomeration. If the transfer and undertaking of manufacturing industries in Hong Kong, Shenzhen, and Dongguan is the driving force behind the economic take-off on the east coast of the Pearl River, then the development of a world leisure and tourism destination integrating Zhuhai and Macao in the first line of Macao and Zhuhai will also be one of the promising prospects. Today, when more attention is paid to the quality of life, Macao, as a foreign trade exhibition platform, is actively seeking to create a livable environment. In the Macao Special Administrative Region City Master Plan (2020-2040) Draft (hereinafter referred to as Macao Planning Draft). The construction of high-quality waterfront space in Macao is in line with the overall plan for Macao in the draft Macao plan.

From the perspective of Macao's planning goals, a very important point in the construction goals of the Macao Special Administrative Region is to build it into a sustainable city and a resilient city. Compared with the main functions of most production-oriented cities in mainland cities, Macao's emphasis on the status quo of the gaming industry has also prompted Macao to actively pursue industrial diversification and transformation and upgrading. Especially in the past 2020, the COVID-19 epidemic has caused a major blow to Macao's tourism industry. Visitors fell by $80 \%$, and the industry diversification index has been sep- 
arately listed on the official website of the Macao Statistics Bureau. Combining the construction of coastal waterfront space, and related constructions aimed at the waterlogging of the city of Macao are also the focus of current attention.

In the overall layout, Macao has drawn the development route of the Waterfront Historical Tourism Axis on the southern shore of the main island of Macao. In the new era, the Macao Special Administrative Region is also actively using its geographical advantages to make full use of the waterfront space.

In the land use planning diagram of Macao, the southern coast area of Macao's main island is also planned as a green space and public open space area, combining the tourist and entertainment area near the Fisherman's Wharf with the commercial area of the Macao Inner Harbor. Macao will have a plan for the construction of waterfront space around the island, but there is currently a lack of research on the current situation of waterfront space utilization. The Macao Planning Draft generally emphasizes the future construction of Macao's high-quality waterfront space and strengthens the protection and utilization of Macao's waterfront space.

\section{Research on the Use of Waterfront Space in Macao}

The waterfront space of the Macao Peninsula can be roughly divided into 7 areas: Fai Chi Kei District, Macao Haojiang Inner Harbor Area, West Bay Lake area, Nanwan Lake Area, Expressway area on the south side of the main island of Macao, The area around the Fisherman's Wharf, The area around the Reservoir.

\subsection{Fai Chi Kei District}

The Fai Chi Kei area is composed of three parts: Sorrento north [Figure 1], Sorrento south [Figure 2], and Linmao Beach Road [Figure 3]. The Fai Chi Kei area is deep in the waters of the inner harbour. From Qingtao Building along Patane North Street to Kuaida Building, residents along the coast can see the complete waters and the landscape on the other side. The water itself is not highly fluid, and the shore base is floated by rubbish. The traffic volume of ships is small, and the functional ships that are parked and used less frequently have become a static landscape. There is no peculiar smell, the road scale is small, the traffic volume is not high, and the noise generated is low. The road along the waterfront space is paved with a combination of large blocks of ashlar and small black bricks, and the greening is made into small trees. The effect itself is average, but there is a special awning on the waterfront for summer use and plenty of seats. The coast is currently under maintenance, and the view to the water is blocked by a simple baffle. The coastal areas are mainly mixed-function commercial and residential buildings, which have no qualitative impact on the waterfront space.

The waterfront space along the Sorrento and the GuangDa middle schools in Macao has a large scale, forming a large activity space. Fitness equipment is concentrated in the small square at the west, and the water surface is open. 


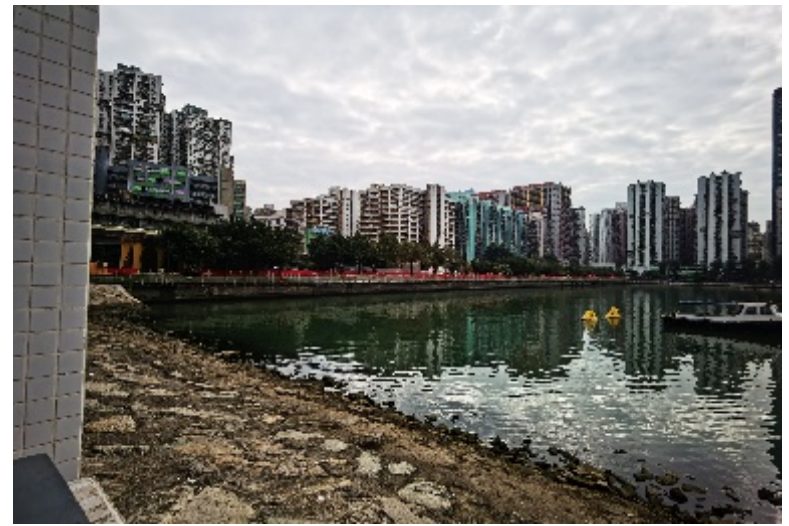

Figure 1. Sorrento north (2021) (The picture was taken by the author).

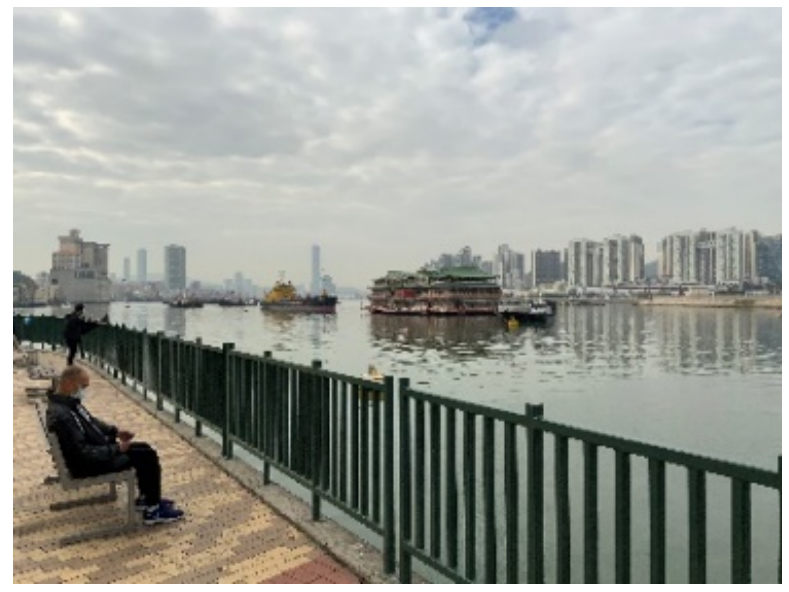

Figure 2. Sorrento south (2021) (The picture was taken by the author).

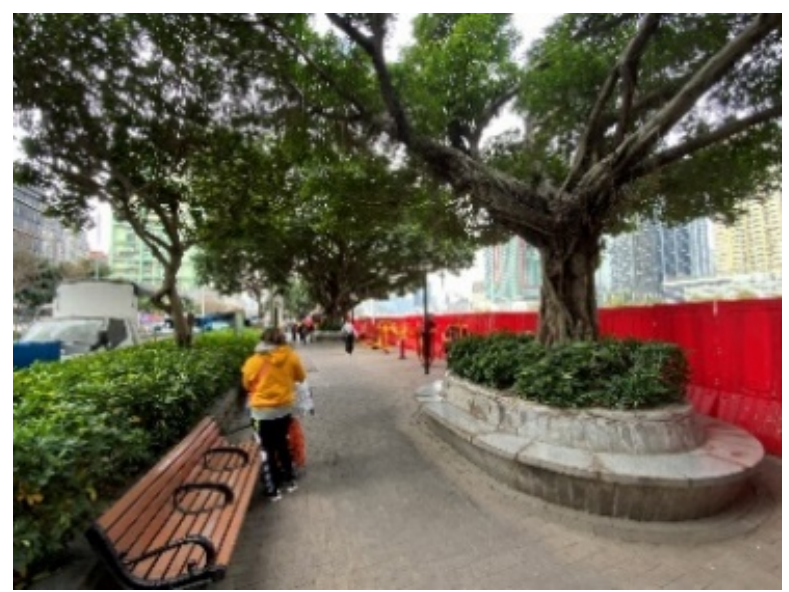

Figure 3. Linmao Beach Road (2021) (The picture was taken by the author).

The water surface of Xiangnan Shipyard along Chuan'ao Street is blocked by buildings. The road to the waterfront of Linmao Seaside Road is wide, and banyan trees with a wide canopy are planted to form enough green space. At the same time, thick greening separates the road from the waterfront pedestrian space, and most citizens walk and stay here. 


\subsection{Macao Haojiang Inner Harbor Area}

The Haojiang Inner Harbor Area is composed of three parts: 16th Ponte Holiday Village north [Figure 4], 16th Ponte Holiday Village [Figure 5], 16th Ponte Holiday Village south [Figure 6]. The waterfront of the Inner Harbor of Macao

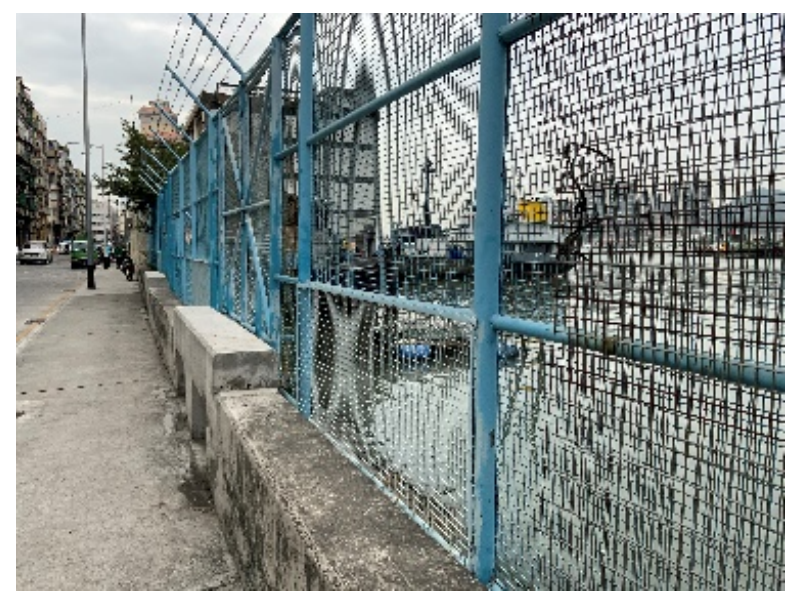

Figure 4. 16th Ponte Holiday Village north (2021) (The picture was taken by the author).

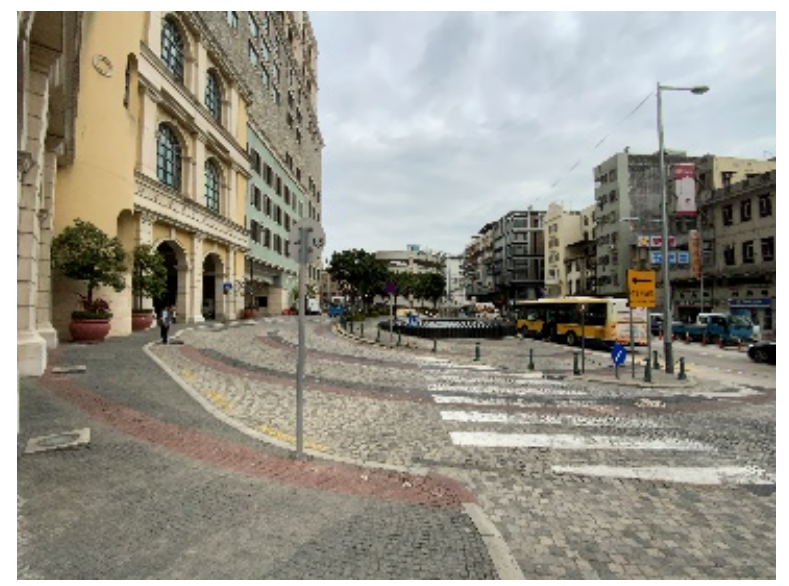

Figure 5. 16th Ponte Holiday Village (2021) (The picture was taken by the author).

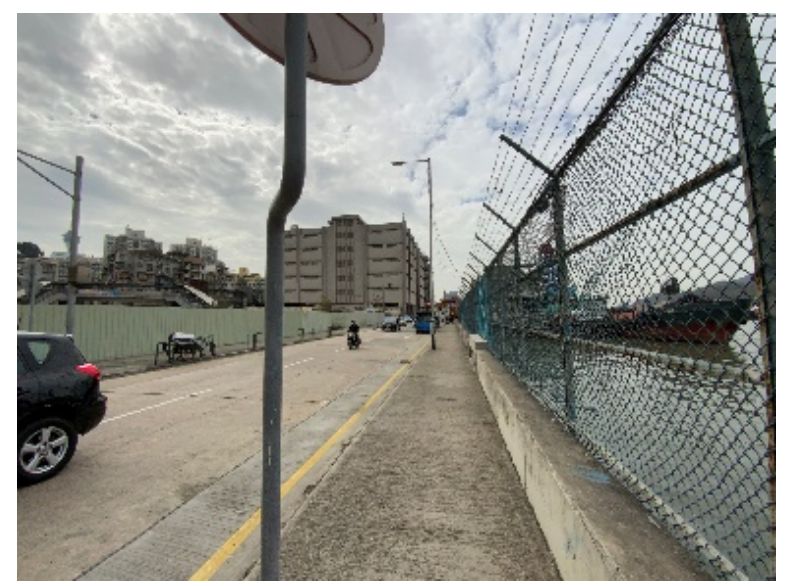

Figure 6. 16th Ponte Holiday Village south (2021) (The picture was taken by the author). 
is located on the west side of the Macao Peninsula. It is the port area with the longest history and the first to be developed in Macao. From the 19th century to the 1930s, the coastline was gradually reclaimed to expand the land, forming the current pattern of the old city of Inner Harbor to Zhuhai Wanzai [9].

From the Harbour Building to Pier 34, head south along the Damei Diao Shi Nadi Road to Huo Chuantou Street, then south to Bili Lama Jishi Street, and then south until the A-Ma Temple bus stop can be used as the front mountain of Macao overview of the area along the waterway. The coastal area of the inner port is mainly used as a cargo port. The factory and warehouse of the freight company have coastal space. It is difficult to directly see the waterfront space from the road open to the public. The presence of water in this area is very low. The cargo ships traveling to and from the inner harbour are repellent from the exhaust emissions and the roar of the engines. The streets are mainly used for freight docks to enter and ship on land. The sidewalks are inconsistent, and the large construction vehicles passing through are safe for pedestrians. The road is simple concrete paving, there is not enough space for greening, lack of shading, and no facilities or equipment for passers-by to stay. The overall service is efficient, and some sections of the road are cross-flowing with sewage and the environment is poor. The buildings on the coastal side are mainly low-rise factories and office buildings, which are gathering places for trucks. The buildings on the inland side are mainly multi-storey commercial and residential buildings, and the ground floor businesses are mainly hardware stores and auto repair services that serve the freight terminal. The positioning of the region in the city tends to be a logistic service module, not a construction direction for the purpose of public service waterfront open space.

In particular, in the Yan'an area of Qianshan Waterway, there is the 16th Ponte Holiday Village. Like other buildings, it also blocks the view from the street to the water surface space, but the roads within its area are well paved, lower than the surrounding unmodified concrete, and the ground around Ponte 16 (Macao) is clean, providing a spacious front. The square is used by citizens, and the ground has been meticulously paved, from the square tiles on the edge to the fine stone paving of the high platform, and then to the polished and smooth floor tiles under the corridor. The ground is neat and tidy. Green planting was done in the entrance plaza to ease the continuous hard interface and provide shade.

\subsection{West Bay Lake Area}

West Bay Lake is smaller than Nanwan Lake, and its shoreline is naturally tortuous, making it impossible to see the lake at a glance. It has a sense of mystery and arouses people's desire for exploration. West Bay Lake is surrounded, and the lake is calm and has no peculiar smell [Figure 7]. Motor vehicles on the north bank have slower speeds and low noise, while the south bank is relatively noisy. The road is an old stone road and low stone fence. The distance between pedestrians and the water surface is close, which has a strong affinity. Planting 


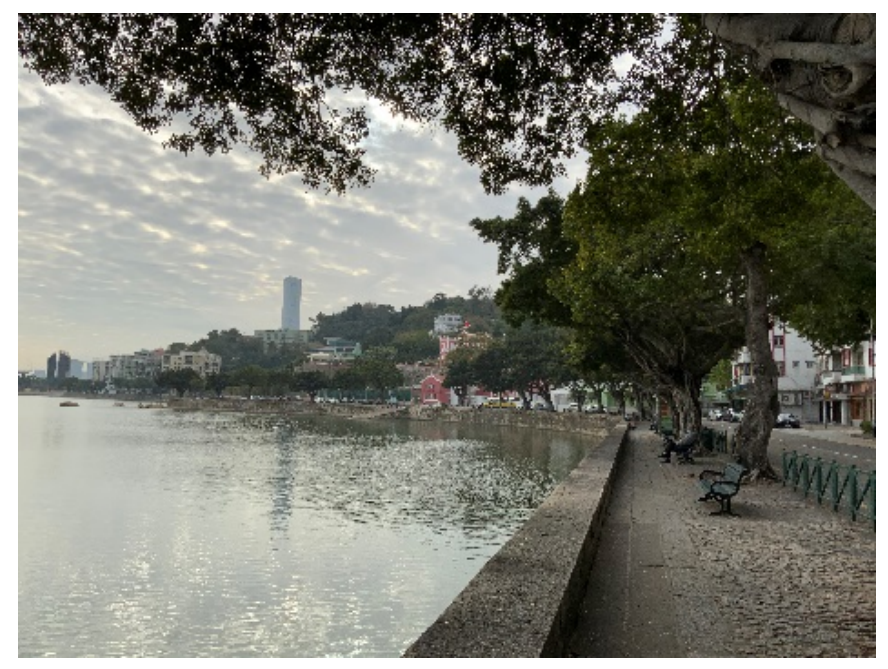

Figure 7. West Bay Lake (2021) (The picture was taken by the author).

banyan trees, the wide canopy becomes a good natural shade. There are many benches on the narrow roads, and residents often exercise here. The coast of the northern part of West Bay Lake is mostly residential areas with multi-storey houses, which affects the waterfront space of West Bay Lake to become an important destination for residents' daily leisure.

\subsection{Nanwan Lake Area}

The Nanwan Lake Area is composed of three parts: North bank of Nanwan Lake Area [Figure 8], East bank of Nanwan Lake Area [Figure 9], Arc bank of Nanwan Lake Area [Figure 10].

The center of the fan-shaped Nanwan Lake is the front area of Yamala, the tourist and entertainment center of the Macao Peninsula. It has a developed economy and concentrated industries, which has the meaning of a city center. There are small islands in Nanwan Lake, which form the foreground, middle and long distance with the tall landmarks on the other side of the lake and in the distance, forming a richly layered visual scene. Looking south from the north side of Nanwan Lake, the wide view will be independent of Macao Closed by the sightseeing tower, looking north from the south bank of Nanwan Lake, in the distance are the monumental Lisboa Hotel, Wynn Hotel, and Lake One. The water body is relatively clean. Nanwan Lake is an inner lake. There are only a few sightseeing boats on the lake. The shore of the lake is basically separated from the motorway, with less noise and fresh air. Although Nanwan Lake is small, the pedestrian roads along the coast are not continuous and have been interrupted in many places, requiring a long detour to return to the waterfront area. Palm trees with smaller tree crowns are planted around. On the north side, there is an arcade with southern characteristics. The huge scale creates a huge and rhythmic corridor space, but it is repeatedly interrupted to form an end, and the flow of people is sparse. There are spacious public waterfront activity spaces in the northwest and southwest corners of the curved shoreline. There is also a 


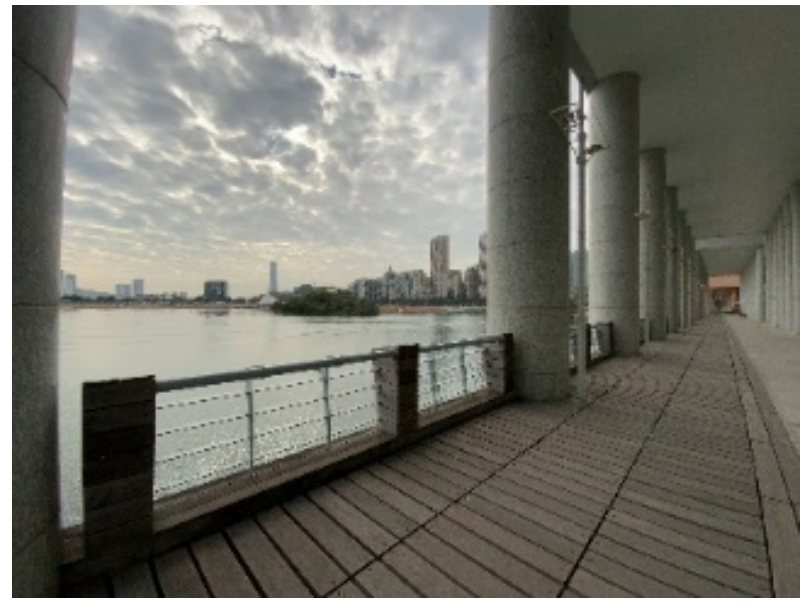

Figure 8. North bank of Nanwan Lake Area (2021) (The picture was taken by the author).

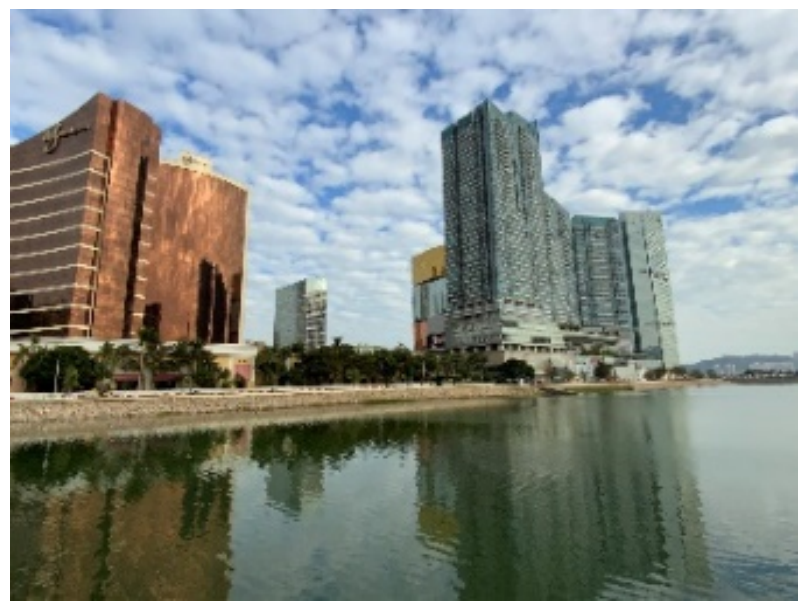

Figure 9. East bank of Nanwan Lake Area (2021) (The picture was taken by the author).

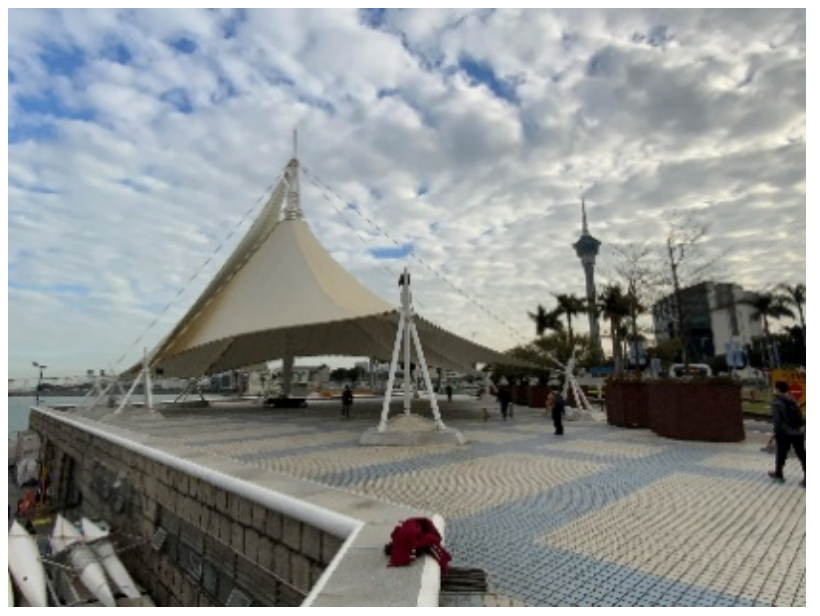

Figure 10. Arc bank of Nanwan Lake Area (2021) (The picture was taken by the author).

lack of exercise equipment, and the activities in the space mainly rely on the people's spontaneous activities. The regional buildings are mainly concentrated in the north and east. The eastern buildings are mainly Wynn and Lake One. 
The pedestrian space is spacious. There are entrance plazas on both sides of the north and south. The commercial and entertainment buildings objectively improve the quality of the waterfront space, but the control is not strong. In essence, it is still a public-oriented space; the northern pedestrian area is located in the inner corridor provided by the building, and the shops are shrunk inside the building, which has less impact on the space and is also a public-oriented space.

\subsection{Expressway Area on the South Side of the Main Island of Macao}

This area is composed of five parts: A-Ma Temple-Free Wave Land [Figure 11], Free Wave Land -Macao Tower [Figure 12], Nanwan Lake entrance [Figure 13], No.1 Square South-Guanyin Statue [Figure 14], Guanyin Statue-Macao Science Museum [Figure 15].

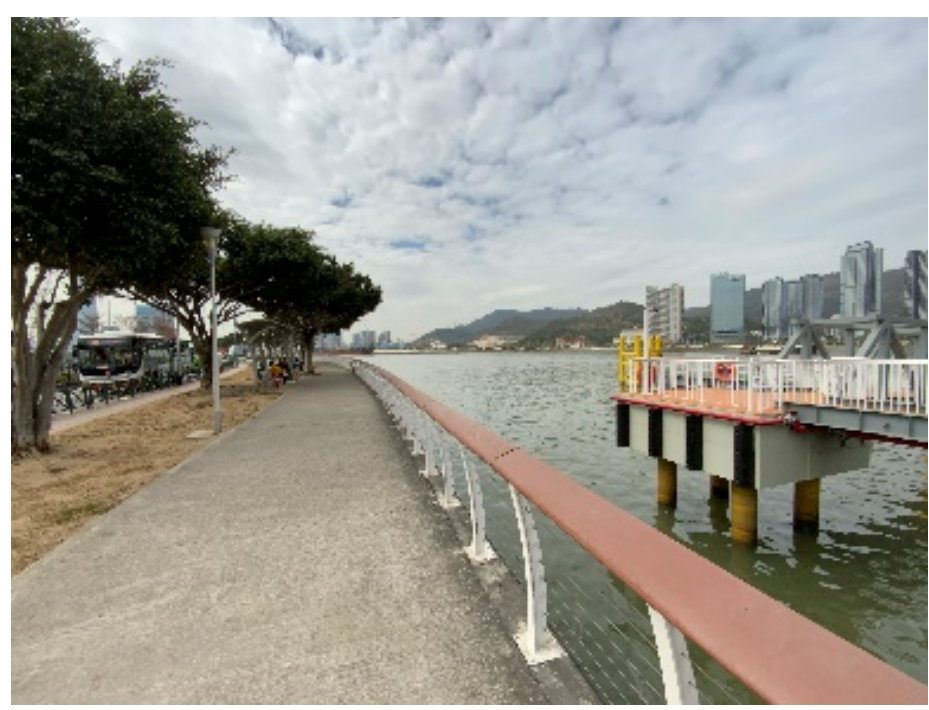

Figure 11. A-Ma Temple-Free Wave Land (2021) (The picture was taken by the author).

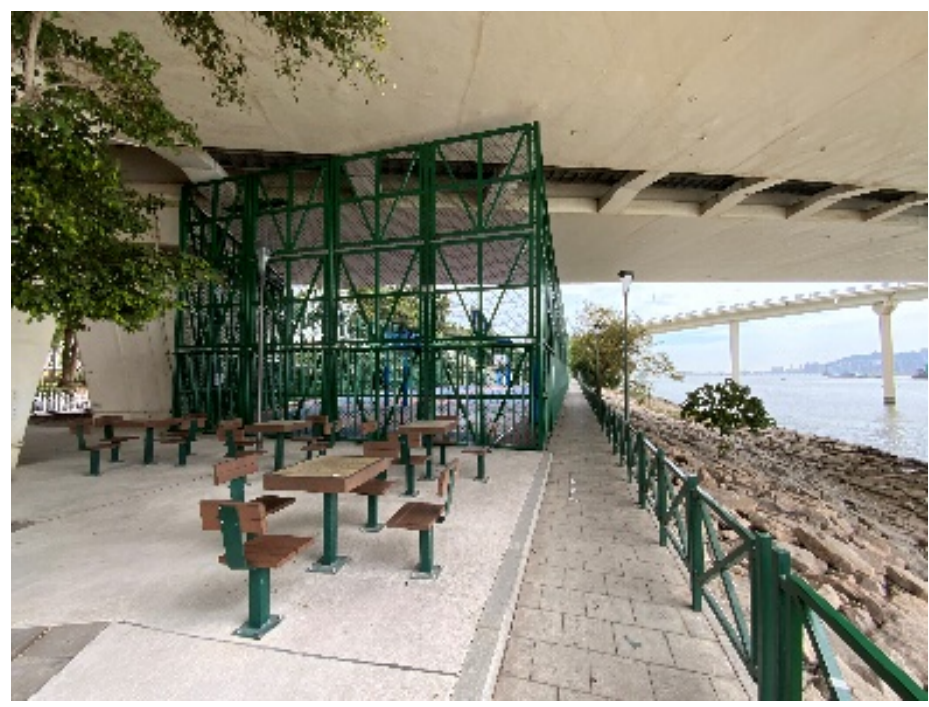

Figure 12. Free Wave Land-Macao Tower (2021) (The picture was taken by the author). 


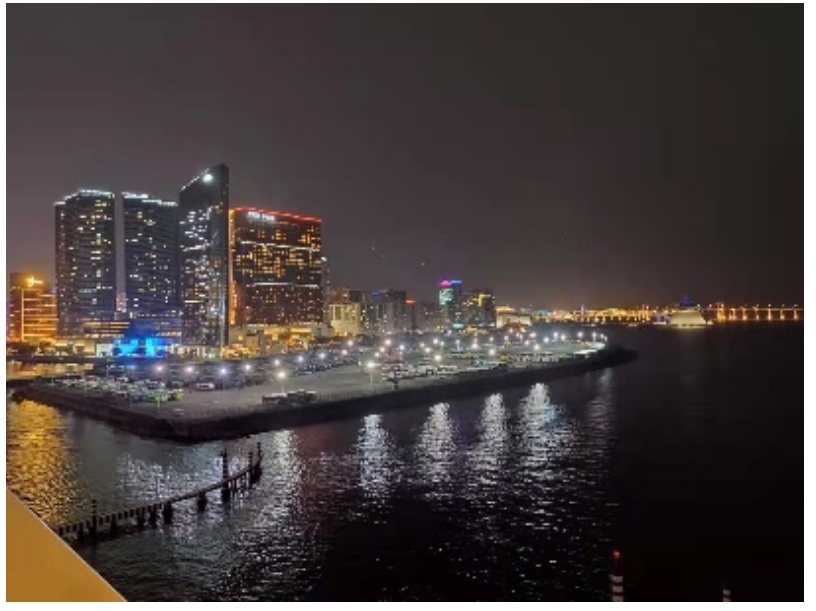

Figure 13. Nanwan Lake entrance (2021) (The picture was taken by the author).

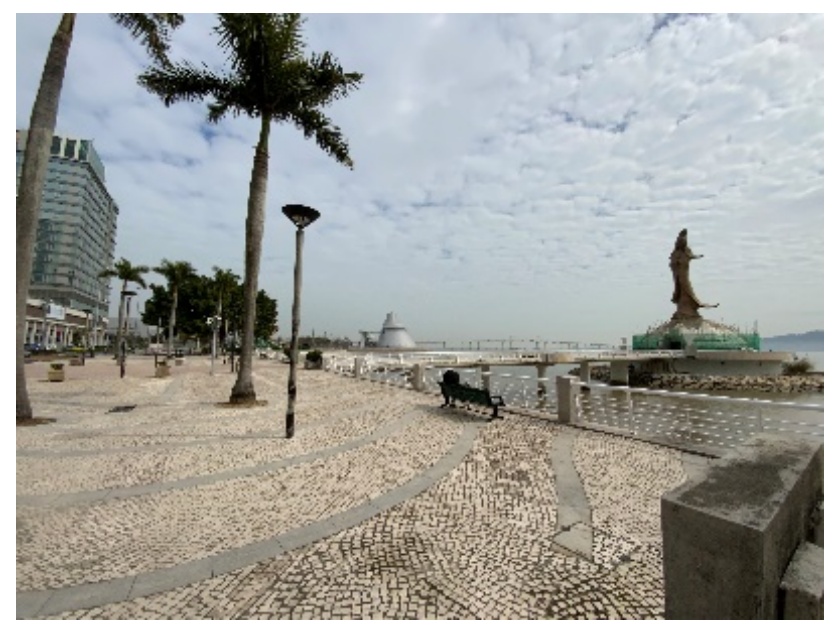

Figure 14. No.1 Square South-Guanyin Statue (2021) (The picture was taken by the author).

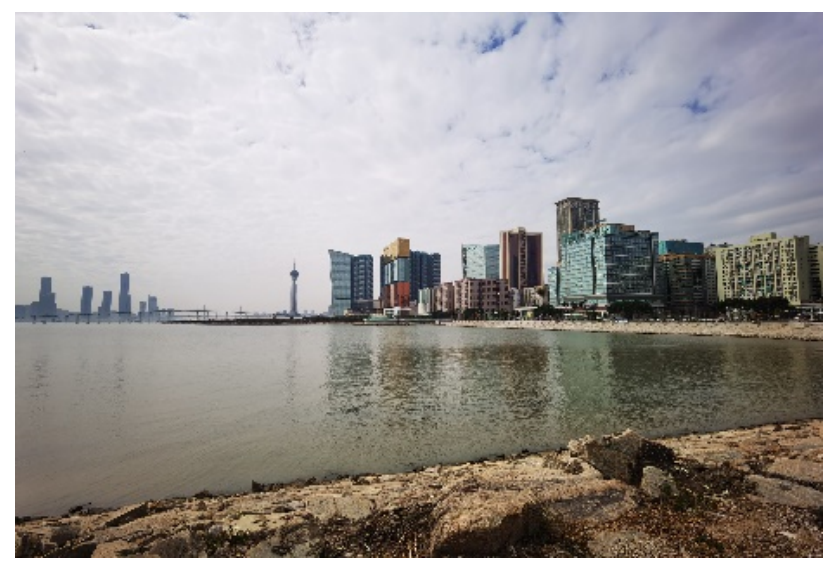

Figure 15. Guanyin Statue-Macao Science Museum (2021) (The picture was taken by the author).

From the A-Ma Temple bus station along the riverside new street to the southeast to the front of Macao Tower. With a wide view, the Zhuhai Interna- 
tional Convention and Exhibition Center is on the opposite side of the sea. The Shizimen water area composed of Zhuhai and Macao has a lot of boat traffic, which is one of the sources of interesting walking. The new street by the river is mainly the approach part of the West Bay Bridge. It is an urban expressway. The pedestrian part of the road is narrow. The design does not encourage pedestrians to wander there. The relevant attractive stay arrangements such as greening, sunshade, resting seats and The equipment were not placed in the western half. The West Bay Bridge approach bridge and the three-dimensional transportation facilities occupy a large area of land. The land except for transportation is used. Free waves are set up under the West Bay Bridge and the West Bay Lake View Avenue near the Macao Tower, with rest seats, basketball courts, etc. Facilities, and people will be kept from the north side of the road, that is, the side of Xiwan Lake, to the free wave ground event venue through the human nature bridge. There are parking lots in the surrounding area, which does not make Balti an "abandoned enclave."

The sea view area on the south side of the Macao Tower is unique to the Macao Tower. The continuous coastal road is far away from the open sea. The seaside area of the Macao Tower is fenced for internal visitors. The area is mainly composed of complex three-dimensional transportation with less greenery. Except for the Macao Tower, there is a lack of shading. A large area is vacated for public activities. It is mainly a basketball court. It is one of the large areas of the island where sports activities can be carried out.

The estuary area on the south side of Nanwan Lake. As the double gate of Nanwan Lake's estuary, the area is huge but inconsistent. It becomes a traffic bag-like "end road" in a certain sense. Both the east and west are peninsula-shaped areas facing the water on three sides. Currently, it is a bus parking lot. Lack greening, shading and rest facilities. The sea on the south side is mainly used as an attachment to the roadway of Sun Yat-sen Road. The current construction lacks the objective material construction required for walking affinity and is not suitable for pedestrians to stay.

It is worth mentioning that the construction of the pedestrian road on the right side of the Gallup Governor's Bridge and the south side of MGM is in good condition. Small square brick mosaics are used, green and yellow plants are planted alternately, and there is a lack of sun protection and rest. Neither shopping malls nor casinos occupy the waterfront interface, but the view towards the water here is blocked.

The area from the Guanyin statue to the Macao Science and Technology Museum has a good view. The protruding Macao Science and Technology Museum forms a "concave coast" in the area, and the citizens have something to see at both ends. The flowing water itself has no peculiar smell. The fast-moving vehicles have a certain noise impact on the waterfront space, and to a certain extent they also prevent citizens from the north side of Sun Yixian Road to the south side of the waterfront. The road is paved in good condition. However, the lack of greenery sufficient to shade, the hot summer in the south will reduce 
people's willingness to use the waterfront space. In the square in front of the Macao Science and Technology Museum, there are a large number of seats integrated with the landscape, but the form is monotonous and repetitive, and lacks interest. The facilities in the space are low and the square space can be seen at a glance. The road has a large scale and few surrounding buildings. The only thing that controls the area is the Macao Science and Technology Museum. Its public building attributes also make the surrounding area have real public attributes, and the area is dominated by open waterfront space. The waterfront space on the west side of the Science and Technology Museum is a public parking lot.

\subsection{The Area around the Fisherman's Wharf}

This area is composed of three parts: Babylon Entertainment Plaza [Figure 16], Les Hotel-Fisherman's Wharf, Legend Palace Casino [Figure 17].

The area from the parking lot of the Macao Science and Technology Museum to the north of the Macao Outer Harbor Passenger Terminal is mainly a tourist and entertainment area. Although the waterfront space is mainly within the actual influence of high-end hotels and casinos, the waterfront space is open to the

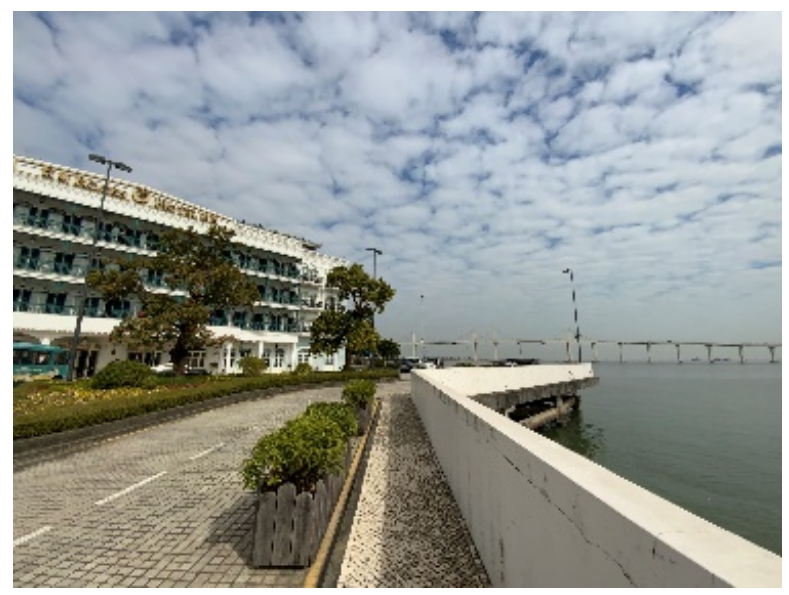

Figure 16. Babylon Entertainment Plaza (2021) (The picture was taken by the author).

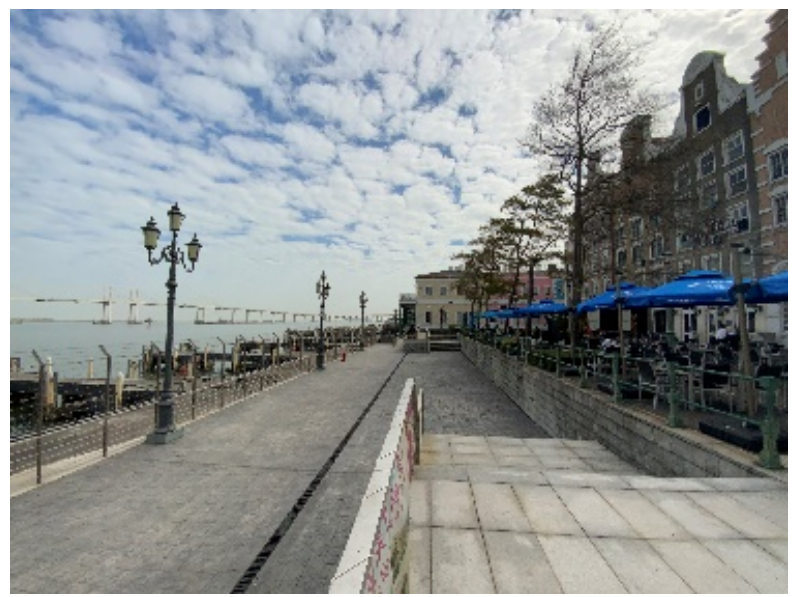

Figure 17. Les Hotel-Fisherman's Wharf (2021) (The picture was taken by the author). 
public. In terms of vision, the waters in this area have a strong presence, but the piers of the Friendship Bridge dominate the vision. The water itself is flowing sea water, and the air is fresh and odorless. The area is mainly within the range of shops and hotels and casinos. The pavement is clean and tidy, mixed with wooden floors and square tiles. The green tree canopy is smaller and shorter in height and does not obstruct the view of the subsequent houses to the outer harbour. The rest space is mainly provided by the dining table of the waterfront restaurant, which serves the restaurant and has a heavier commercial atmosphere. There are a lot of vacant spaces during non-dining peak periods, and there are fewer facilities for public services. The regional waterfront space is oriented towards coastal commerce.

\subsection{The Area around the Reservoir}

The area around the Reservoir [Figure 18] is a leisure place for residents on the waterfront that Macao intends to build. The scale is moderate, and the trail across the bank can be seen across the storage pond. The surface of the water is calm, and the air circulates without peculiar smell. There are busy four-lane highways around, but the trails have been elevated, and some areas are surrounded by greenery to isolate the noisy motor vehicle lanes from the public walking space in the Reservoir. The trail around the storage pond is decorated with paving of different textures. The west side is mainly paved with red-brown and creamy yellow bricks. The south, east and north sides are mainly paved with traditional beige bricks in Macao. In order to take care of the feeling of running citizens, the trail around the Reservoir has a flat road with mileage engraved on it to facilitate exercisers to plan their exercise volume. The greening tree canopy is not large and does not block the long-distance vision. In addition to tree shading, there are special shading pavilions in the area, and there is a continuous long shading corridor [Figure 19] on the south side of the trail around the Reservoir. There are plenty of fitness equipment [Figure 20] on all four sides of the square storage pond.

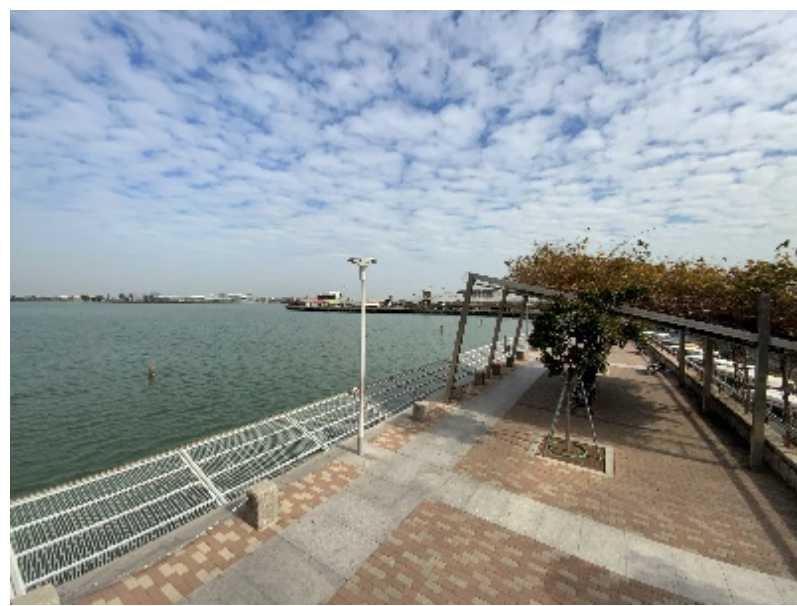

Figure 18. Reservoir (2021) (The picture was taken by the author). 


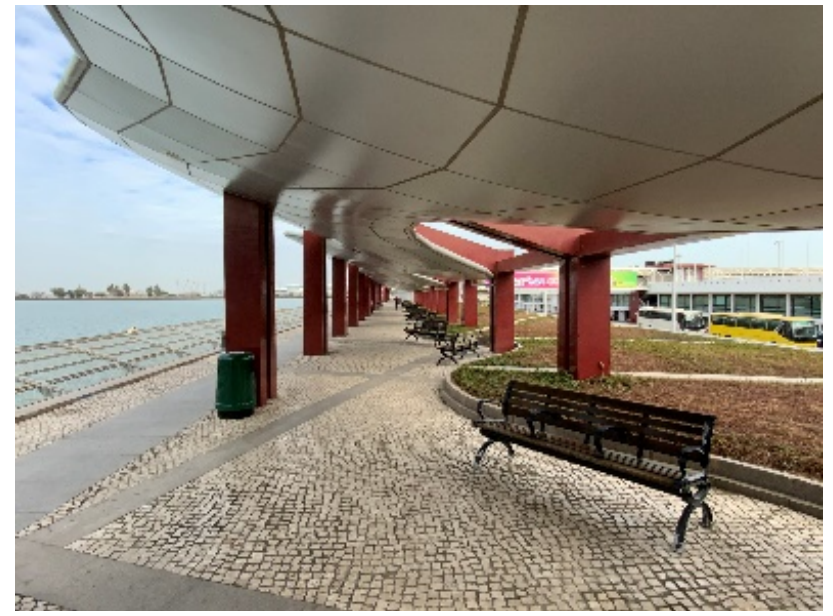

Figure 19. Shading corridor (2021) (The picture was taken by the author).

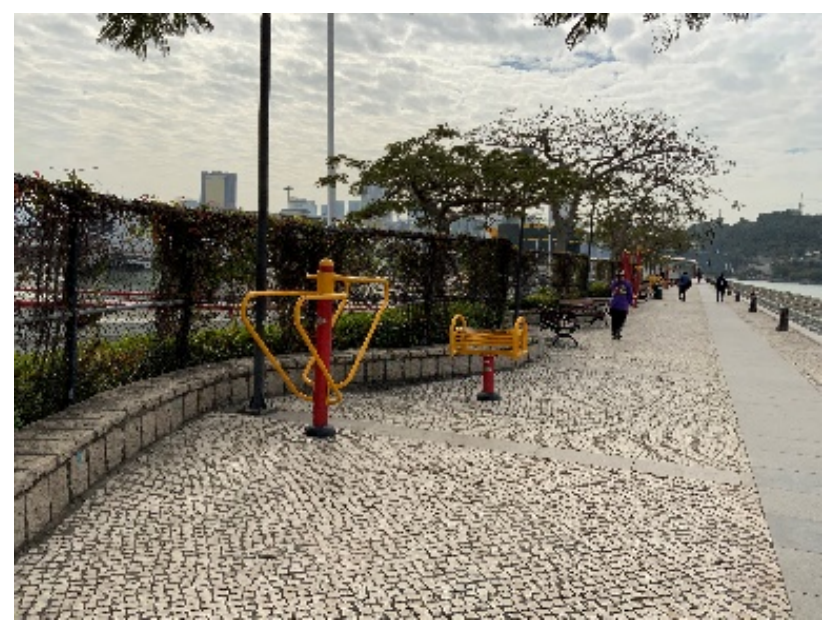

Figure 20. Fitness equipment (2021) (The picture was taken by the author).

\subsection{The Overall Status Quo of Waterfront Space Construction in Macao}

The construction of waterfront space in the city of Macao is relatively well completed. In general, the construction of coastal waterfront space in tourism and entertainment areas and residential areas is better than other regions. This shows that the special zone gives priority to residents' experience and tourist experience, and promotes the gradual improvement of the overall construction level. Development trend. At the same time, the lake in the waterfront space has a higher affinity than the outer sea, and the waterfront interface is more complete and accessible. Coastal formats have a profound impact on the affinity of waterfront space.

From the external perspective of the main island of Macao, the land border is roughly on the north, and the east, west, and south are facing the sea, showing different development trends. The inner port area in the western part of the main island of Macao is oriented towards urban logistics functions. The endpoints of the freight flow line are scattered along the coast of the inner port area 
and are not waterfront leisure places serving ordinary residents; the outer sea side of the southern part of the island is dominated by express roads. The density of space construction is low, and the continuity is poor. The main activity spaces are distributed near the Macao Tower, Guanyin Statue, and Southeast Science Museum; the eastern and southern part of the island is dominated by tourism and entertainment, and coastal shops and hotels have strong control over waterfront space. Waterfront service facilities are mostly provided by hotels and restaurants along the coast to serve their customers, and lack of service facilities for ordinary tourists.

From the perspective of the coast of the inner lake of Macao's main island, the Reservoir area is an open waterfront space that mainly serves residents in Macao, with good openness and high residents' willingness to play; the construction of the coast of Nanwan Lake is greatly affected by Macao's developed tourism and entertainment industry. The waterfront space facilities are relatively new, the space scale is large, and the surrounding buildings are magnificent; the multi-storey residential areas and villas along the West Bay Lake in Macao dominate, quiet and comfortable.

We will use the indicators of vision, road connections, activity venues, greening, shading, seats, and seats to evaluate the completeness of the infrastructure on the island of Macao [Figure 21]. If there is a more complete infrastructure, assign a value of 1 , otherwise assign a value of 0 [Table 1 .

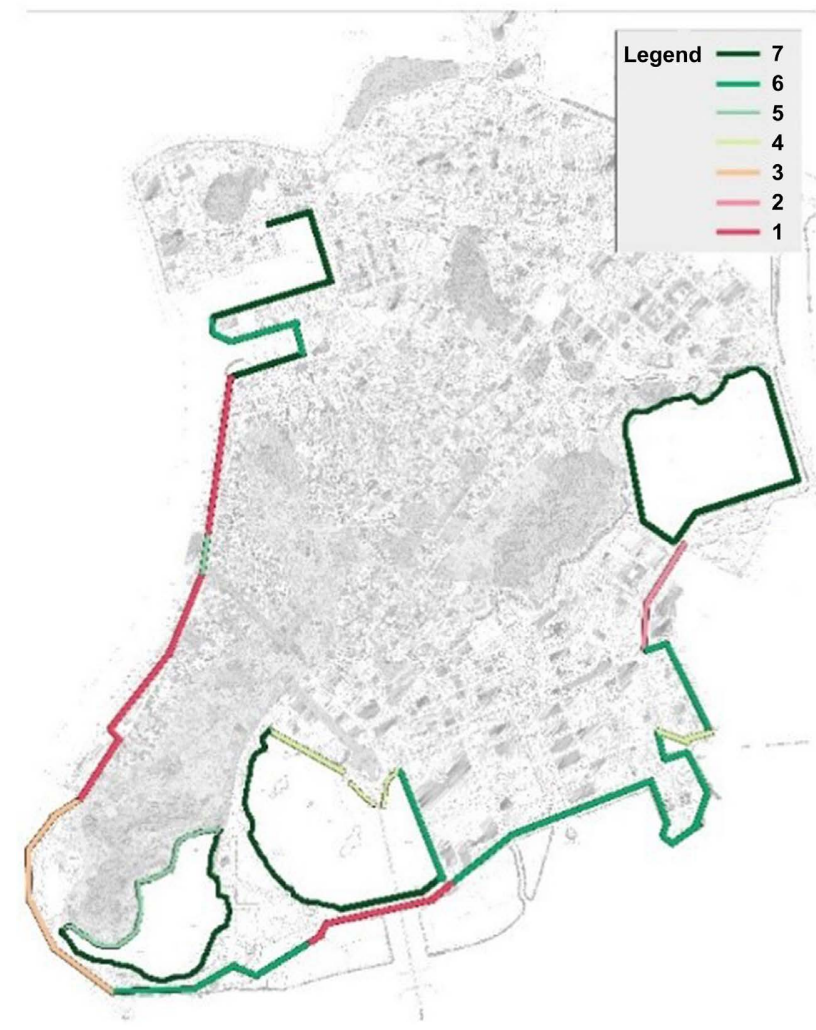

Figure 21. Distribution of 7 waterfront spaces in Macao (The picture was taken by the author). 
Table 1. Evaluation table for perfection of waterfront infrastructure in Macao Peninsula.

\begin{tabular}{|c|c|c|c|c|c|c|c|c|c|}
\hline Evaluation area & Evaluation index & vision & $\begin{array}{c}\text { road } \\
\text { connections }\end{array}$ & $\begin{array}{l}\text { activity } \\
\text { venues }\end{array}$ & greening & shading & seats & seats & Sum \\
\hline \multirow{3}{*}{ The Fai Chi Kei } & Sorrento north & 1 & 1 & 1 & 1 & 1 & 1 & 1 & 7 \\
\hline & Sorrento south, & 1 & 1 & 1 & 1 & 1 & 1 & 0 & 6 \\
\hline & Linmao Beach Road & 1 & 1 & 1 & 1 & 1 & 1 & 1 & 7 \\
\hline \multirow{3}{*}{$\begin{array}{c}\text { The Haojiang } \\
\text { Inner Harbor } \\
\text { Area }\end{array}$} & 16th Ponte Holiday Village north & 0 & 1 & 0 & 0 & 0 & 0 & 0 & 1 \\
\hline & 16th Ponte Holiday Village & 1 & 1 & 1 & 1 & 1 & 0 & 0 & 5 \\
\hline & 16th Ponte Holiday Village south & 0 & 0 & 0 & 1 & 0 & 0 & 0 & 1 \\
\hline \multirow{3}{*}{$\begin{array}{c}\text { West Bay Lake } \\
\text { area }\end{array}$} & North bank of Nanwan Lake Area & 1 & 1 & 0 & 1 & 1 & 1 & 0 & 5 \\
\hline & South bank of Nanwan Lake Area & 1 & 1 & 1 & 1 & 1 & 1 & 1 & 7 \\
\hline & East bank of Nanwan Lake Area & 1 & 1 & 1 & 1 & 1 & 1 & 1 & 7 \\
\hline \multirow{3}{*}{$\begin{array}{c}\text { The Nanwan Lake } \\
\text { Area }\end{array}$} & North bank of Nanwan Lake Area & 1 & 0 & 1 & 1 & 1 & 0 & 0 & 4 \\
\hline & East bank of Nanwan Lake Area & 1 & 1 & 1 & 1 & 1 & 1 & 0 & 6 \\
\hline & Arc bank of Nanwan Lake Area & 1 & 1 & 1 & 1 & 1 & 1 & 1 & 7 \\
\hline \multirow{5}{*}{$\begin{array}{l}\text { Expressway area } \\
\text { on the south } \\
\text { side of the main } \\
\text { island of Macao }\end{array}$} & A-Ma Temple-Free Wave Land & 1 & 1 & 0 & 1 & 0 & 0 & 0 & 3 \\
\hline & Free Wave Land-Macao Tower & 1 & 1 & 1 & 1 & 1 & 0 & 1 & 6 \\
\hline & Nanwan Lake Entrance & 0 & 0 & 0 & 1 & 0 & 0 & 0 & 1 \\
\hline & No.1 Square South-Guanyin Statue & 1 & 1 & 1 & 1 & 1 & 1 & 0 & 6 \\
\hline & Guanyin Statue-Macao Science Museum & 1 & 1 & 1 & 1 & 1 & 1 & 0 & 6 \\
\hline \multirow{3}{*}{$\begin{array}{c}\text { The area around } \\
\text { the Fisherman's } \\
\text { Wharf }\end{array}$} & Babylon Entertainment Plaza & 1 & 1 & 0 & 1 & 1 & 0 & 0 & 4 \\
\hline & Les Hotel-Fisherman's Wharf & 1 & 1 & 1 & 1 & 1 & 1 & 0 & 6 \\
\hline & Legend Palace Casino & 0 & 0 & 0 & 1 & 1 & 0 & 0 & 2 \\
\hline Reservoir & Reservoir & 1 & 1 & 1 & 1 & 1 & 1 & 1 & 7 \\
\hline
\end{tabular}

(The form is made by the author).

We marked the waterfront space evaluation in the Macao Peninsula area from 1 - 7 with different colors [Figure 22]. Then classify the waterfront space formats in the Macao Peninsula, summarize the spatial evaluations of different formats, calculate the average value of each type of formats, and measure the overall evaluation of the different formats of the waterfront space of the Macao Peninsula, so as to draw the pros and cons of different formats on the Macao peninsula as a whole [Table 2].

\section{Enlightenment from the Construction of Macao's Superior Waterfront Area}

\subsection{The Impact of Location on Waterfront Construction}

The waterfront space adjacent to the residential area of the main island of Macao will receive more attention and generate greater demand for use. In particular, Macao belongs to an economically developed area. After people's most basic 


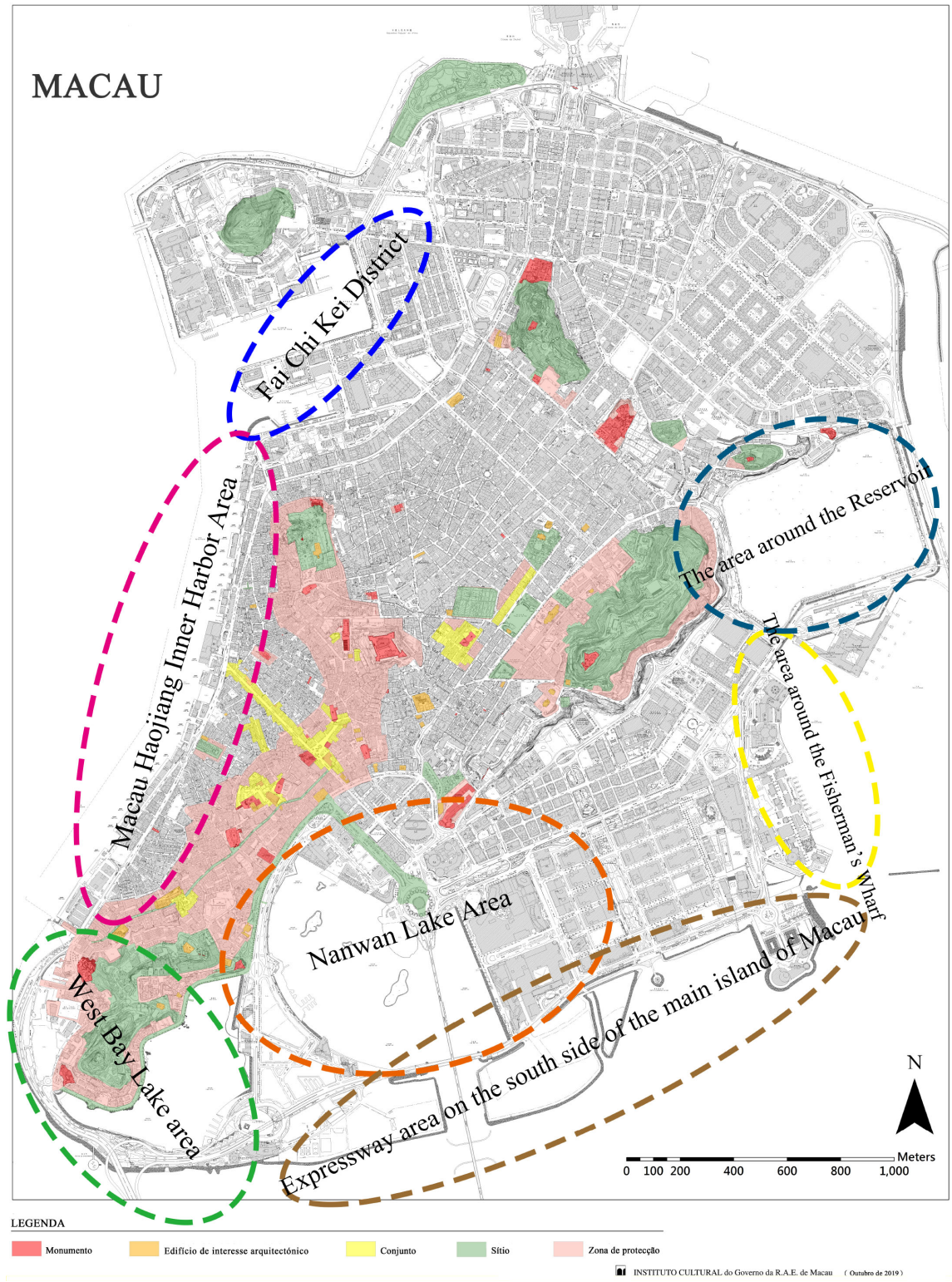

Figure 22. Spatial distribution of waterfront formats in Macao Peninsula (the picture was made by the author).

Table 2. Summary table of classification of formats in Macao Peninsula.

\begin{tabular}{ccc}
\hline Area & Formats & $\begin{array}{c}\text { Evaluation Index } \\
\text { (See Table 1) }\end{array}$ \\
\hline East bank of West Bay Lake area & Public & 7 \\
Arc bank of Nanwan Lake Area & Public & 7 \\
A-Ma Temple-Free Wave Land & Public & 3 \\
Nanwan Lake Entrance & Public & 1 \\
Guanyin Statue-Macao Science Museum & Public & 6 \\
\hline & Public average value & 4.8 \\
\hline Sorrento north & Resident & 7
\end{tabular}




\section{Continued}

\begin{tabular}{ccc}
\hline Sorrento south & Resident & 6 \\
Linmao Beach Road & Resident & 7 \\
North bank of West Bay Lake area & Resident & 5 \\
South bank of West Bay Lake area & Resident & 7 \\
No.1 Square South-Guanyin Statue & Resident & 6 \\
Reservoir & Resident & 7 \\
\hline & Resident average value & 6.42 \\
\hline 16th Ponte Holiday Village north & Business & 1 \\
16th Ponte Holiday Village south & Business & 1 \\
North bank of Nanwan Lake Area & Business & 4 \\
\hline & Business average value & 2 \\
\hline 16th Ponte Holiday Village & Entertainment & 5 \\
East bank of Nanwan Lake Area & Entertainment & 6 \\
Free Wave Land-Macao Tower & Entertainment & 6 \\
Babylon Entertainment Plaza & Entertainment & 4 \\
Les Hotel-Fisherman's Wharf & Entertainment & 6 \\
Legend Palace Casino. & Entertainment & 5 \\
\hline
\end{tabular}

(The form is made by the author).

material needs for food and clothing are met, consumption gradually shifts to satisfying spiritual needs, and the meaning of waterfront space for the people is more obvious. Under these conditions, the benefits of investing in the construction of waterfront space in adjacent residential areas will be more obvious. The infrastructure of the unit can serve more citizens. In contrast, the construction that is far away from the range of civil activities, especially the range within walking distance, will be relatively more obvious. It is said that it is difficult to reach, and the actual utilization rate will also be questionable.

\subsection{The Impact of Industry on the Construction of the Waterfront}

Industry has a positive and negative impact on the construction of the waterfront. The contribution of Macao's tourism and entertainment industry to the entire Macao economy is very obvious. Hotels and casinos provide a comprehensive high-quality service experience. Objectively, the surrounding environment of Macao hotel and entertainment venues will be relatively well constructed. From the main building lobby the exquisite stone road with polished floor tiles and artificial greening such as botanical fountains will enable the surrounding pedestrians to enjoy a comfortable and clean environment. At the same time, the increase in the flow of people brought by the casino will also attract the gathering of the surrounding catering service industry. To provide bet- 
ter services to the surrounding people, especially the tourism, entertainment of the main island of Macao are mostly built in the waterfront space. For example, the Ponte 16 Resort node is very prominent in the overall environment along the Haojiang Inner Harbor. But on the other hand, the closed management of the waterfront space by large-scale industries will cause the waterfront corridor to break, and the inward business model of the casino will also make the use of the waterfront space limited, even as a parking lot. Therefore, the industry needs to be guided to produce beneficial effects for the citizens in the use of waterfront space.

\subsection{The Impact of Traffic on Waterfront Construction}

For coastal cities, such as Macao, the waterfront space mainly spreads along the coastline. Urban expressways are often laid along the coastline. The expressways block the urban waterfront space from the flow of people in the main urban area. The roads originally used to improve the accessibility of urban areas tend to reduce the accessibility of the waterfront space. If the main urban area is separated from the waterfront space by an expressway, three-dimensional traffic must be used to guide the flow of people to the coastline. On the other hand, for Neihu Space, having a closed-loop transportation system can enhance its sense of space.

\subsection{The Impact of the Construction of the Waterfront Space Itself}

The construction of the waterfront space itself can improve the unfavorable factors in its environment. For example, the surrounding storage pond space can improve the flood control capacity of the area and make the noise of the motor vehicle lanes by raising the embankment.

\subsection{Waterfront Space Construction Potential}

Macao currently has a certain amount of waterfront space to be developed. The estuary area on the south side of Nanwan Lake is a part of the continuous landscape of Nanwan Lake on the left and right. It is a large peninsula-shaped high-quality waterfront space and an important gateway to the island's tourist and entertainment center. There is also room for development on the south side of the Babylon Casino in the southeast corner. In the future, Macao will add new reclamation areas, and there is still potential for the construction of urban waterfront space.

\subsection{The Influence of Cultural Memory on Waterfront Space Construction}

As an island city, Macao people have deep feelings and memories for waterfront space. Over time, the function of waterfront space has tremendously changed. Today's waterfront space is a good place for citizens to exercise and walk. Moreover, it enriches the landscape of waterfront space with vegetation and 
structures. To a certain extent, waterfront space also connects Macao people's memory of past life and culture.

At the same time, this research takes Macao as a case, which has rich waterfront space because of its unique island terrain. In different cities, different situations will appear, and there will be some limitations. We hope we can make it up in the following research.

\section{Conflicts of Interest}

The authors declare no conflicts of interest regarding the publication of this paper.

\section{References}

[1] Al-Shams, A.R., Ngah, K., Zakaria, Z., Noordin, N. and Sawal, M.Z.H.M. (2013) Waterfront Development within the Urban Design and Public Space Framework in Malaysia. Asian Social Science, 9, 77. https://doi.org/10.5539/ass.v9n10p77

[2] Baş Bütüner, F. (2006) Waterfront Revitalization as a Challenging Urban Issue in İstanbul. Waterfront Revitalization as a Challenging Urban Issue, 42nd ISoCaRP Congress, İstanbul, Türkiye.

http://www.isocarp.net/Data/case studies/792.pdf

[3] Gospodini, A. (2001) Urban Design, Urban Space Morphology, Urban Tourism: An Emerging New Paradigm Concerning Their Relationship. European Planning Studies, 9, 925-934. https://doi.org/10.1080/09654310120079841

[4] Wang, Z. and Shen, G. (2020) A Study of Waterfront Space in Macao from the Perspective of Urban Design. Famous Chinese City, No. 6, 34-41.

[5] Sun, S. and Wang, Z. (2004) Research on the Relationship between Urban Waterfront Development and Urban Competitiveness. Planner, No. 8, 5-9.

[6] Li, Q. and Wu, Y. (2020) The Reshaping of the Waterfront Space on the Macao Peninsula in the Consumer Era. Famous Chinese City, No. 5, 26-32.

[7] Yin, Z. (2019) Research on the Design Countermeasures of Macao Urban Waterfront Space Based on the Concept of "Urban Double Repair". Chinese and Foreign Architecture, No. 9, 118-120.

[8] Yu, C. (2009) Transformation of Waterfront Space in Asian Cities: Macau, Hong Kong, Shanghai. The 4th International Conference of the International Forum on Urbanism (IFoU), Amsterdam, 597-606.

[9] Gao, J., Long, Y., Fei, Y. and Gao, Y. (2018) Urban Design Practice and Reflection on the Redevelopment of the Waterfront of the Inner Harbor in Macao. Chinese Garden, No. 12, 78-83. 